\title{
La Biblia y la evangelización del Nuevo Mundo durante el siglo XVI
}

\author{
JUAN LUIS DE LEÓN AZCÁRATE \\ Universidad de Deusto (España) \\ jleon@deusto.es
}

\begin{abstract}
Resumen
El objetivo de este ensayo es mostrar algunos ejemplos del papel fundamental que tuvo la Biblia en la evangelización del Nuevo Mundo durante el siglo XVI. Tres aspectos serán estudiados aquí: 1) el intento inicial de traducir los textos bíblicos a las lenguas indígenas, finalmente frustrado; 2) la importancia de la Sagrada Escritura para dilucidar las estrategias políticas y religiosas a seguir con respecto al Nuevo Mundo, ejemplarizada en la cita de Lc 14,23; 3) los temas bíblicos en el teatro de evangelización.
\end{abstract}

Palabras clave: Biblia, evangelización, hermenéutica, Nuevo Mundo, traducción, teatro.

\section{The Bible and the Evangelization of the New World in the XVI Century}

\begin{abstract}
The aim of this essay is to show some examples of the important role that had the Bible in the evangelization of the New World during the 16th century. Three aspects will be studied here: 1) the initial attempt to translate biblical texts to indigenous languages, finally frustrated; (2) the importance of Sacred Scripture for political and religious strategies to be followed with respect to the New World, exampled on the appointment of Lc 14.23; (3) biblical themes in the theatre of evangelization.
\end{abstract}

Keywords: Bible, evangelization, hermeneutics, New World, translation, theatre.

Profesor titular de Sagrada Escritura y director del Departamento de Teología de la Facultad de Teología de la Universidad de Deusto (Bilbao, España). Autor, entre otras publicaciones, de Santiago, el hermano del Señor (1998); Levítico (2006); La muerte y su imaginario en la historia de las religiones (2007); Deuteronomio (2009); y junto con F. SánchezMarco, Los evangelizadores encuentran al Diablo en el Virreinato del Perú. José de Acosta y la salvación de los indios (2013). 


\section{Introducción}

La Biblia llegó al Nuevo Mundo descubierto en 1492 con los primeros misioneros españoles ${ }^{1}$. Su influjo fue fundamental. No se puede entender el desarrollo del encuentro (y desencuentro) cultural de dos mundos tan distintos como lo fueron el español y el indio (tan variado y complejo éste) sin comprender el papel que jugó la Biblia como instrumento de comprensión y análisis de la nueva realidad. Pero no llegó de manera pura y aséptica sino acompañando, y a veces amparando, un proceso de descubrimiento que también fue de conquista en el que el «otro», el indio, casi nunca salió bien parado (Todorov, 1998). Por esta razón su influjo fue ambivalente, para lo bueno y para lo malo, según el uso que se hiciera de ella, como lo muestran dos episodios muy significativos de cuño muy distinto.

El primer episodio se sitúa en la isla de Santo Domingo, en el adviento de 1511, y su protagonista fue el dominico Antonio de Montesinos, cuyo sermón dominical, en el que denuncia a partir de textos bíblicos la violencia y opresión ejercidos contra los indios, provocó la ira de sus oyentes españoles ${ }^{2}$. El segundo episodio tiene lugar en 1533 en Cajamarca (Perú), y sus protagonistas fueron el también dominico, Vicente de Valverde, integrante de la expedición de Francisco Pizarro, y el Inca Atahualpa, jefe político y religioso del Imperio inca. Fray Vicente, con una Biblia (o quizá un breviario) en la mano, insta, tras una breve catequesis, al Inca a convertirse al cristianismo y a ser amigo tributario del Rey de España. Le entrega el libro a Atahualpa, pero éste, tras ojearlo sin entender nada de lo escrito, rechaza la propuesta y lo arroja contra el suelo $^{3}$. El episodio es conocido, y la ambición de Pizarro y diversas intrigas propiciarán la ejecución de Atahualpa tras recibir el bautismo.

Estos dos significativos ejemplos muestran cómo la Biblia, al menos en un comienzo, fue ciertamente un instrumento de contradicción y de desencuentro entre ambos mundos y culturas. Y lo fue para unos y para otros. En ocasiones, para los mismos españoles cuando era leída con auténtico espíritu profético y evangélico, denunciando sus abusos injustificados de poder, como fue el caso del sermón de Montesinos. Pero también lo fue, y principalmente, para los indios del Nuevo Mundo, quienes inicialmente no la entendían, así como tampoco comprendían

1 El mismo «descubridor» de este Nuevo Mundo, si bien no fue realmente consciente de su novedad, Cristóbal Colón, usó profusamente el texto bíblico para justificar, de modo providencialista, sus propias pretensiones en relación a la tierra a la que arribó; véase León (2006).

2 Las Casas (1994) recoge este sermón en su escrito del 1559, en III, 4-5.

3 Este episodio es descrito, entre otros, por Xerez (1985) en el año 1534. 
por qué debían abandonar la fe y creencias de sus antepasados para adorar a un Dios distinto ofrecido por los mismos extranjeros que les dominaban, como fue el caso de Atahualpa ante fray Vicente.

Fue a comienzos del siglo XVI cuando los jesuitas acuñaron el vocablo «misión», el cual, con el uso, fue adquiriendo un triple sentido, personal, operativo y territorial, de modo que los jesuitas reciben (1) un «envío» personal, que los lleva a (2) desempeñar una tarea al servicio de la propagación de la fe (3) en un determinado territorio. Durante el Medievo, el término missio o «misión» solamente significaba «empeño, esfuerzo, cuidado, gasto». Para nombrar la tarea de la Iglesia de propagar la fe se utilizaban expresiones como conversio infidelium (conversión de los infieles), praedicatio gentium (predicación de los pueblos), promulgatio Evangelii (promulgación del Evangelio), propagatio fidei (propagación de la fe), apostulatus (apostolado), labor evangelicus (labor evangélica), annuntatio evangelica (anuncio evangélico) y novella Christianitatis plantatio (nueva plantación de la cristiandad) ${ }^{4}$.

Pero, lógicamente, el cambio de nomenclatura no significó inmediatamente un cambio radical de metodología evangelizadora. Las conversiones masivas de indígenas al cristianismo durante el siglo XVI (en las que primero se bautizaba y luego se adoctrinaba), fueron de carácter muy similar a las conversiones masivas de otros pueblos de Europa, Asia y África habidas a partir del siglo IV d.C. y a las de los pueblos de Asia meridional y oriental en el siglo V. Y lo hicieron siguiendo el ejemplo de sus curacas o caciques, de igual modo que hicieran antaño los súbditos de Recadero, los pueblos bárbaros, los ortodoxos y las diversas iglesias de la Reforma ${ }^{5}$. Probablemente, las conversiones masivas de los indios americanos del siglo XVI fueron las últimas de la etapa histórica de las conversiones masivas, ya que después de ellas comienza la etapa de las

\footnotetext{
4 Sobre el concepto de «misión» en esta época y su sentido en la Compañía de Jesús, véase Sievernich (2007).

$5 \quad$ En algunos lugares de su obra, el jesuita José de Acosta parece participar de esta mentalidad aunque sea parcialmente. Así, Acosta (1984), recogiendo el parecer de otros, lamenta que los españoles mataran a Atahualpa en lugar de conquistar su voluntad porque, en ese caso, «muy en breve hubiera sucedido haber recibido la fe muy fácilmente todo el imperio de los incas. Porque es maravillosa la sumisión que todos los bárbaros tienen a sus propios reyes y caciques» (I, 18). Más aún, Acosta (2008) sostiene que es más fácil evangelizar a los indios sometidos a un señor, refiriéndose particularmente a los incas y aztecas, que a aquellos que viven más libremente y dispersos: «Es llano que ninguna gente de las Indias Occidentales, ha sido ni es más apta para el Evangelio, que los que han estado más sujetos a sus señores y mayor carga han llevado, así de tributos y servicios como de ritos y usos mortíferos» (VII, 28).
} 
conversiones individuales por las que primero se adoctrina y después se bautiza ${ }^{6}$.

En esta línea, a petición del Real Consejo de Indias, una comisión teológica-misional de 1541 de la Universidad de Salamanca realizó un dictamen que concluye que «los indios no deben ser bautizados antes de ser suficientemente instruidos no sólo en la fe, sino también en las costumbres cristianas, al menos en lo necesario para la salvación, ni tampoco antes de que parezca verosímil que entienden lo que reciben en el bautismo y que quieren vivir y perseverar en la fe y religión cristiana» (Hernández Martín, 2004). Este dictamen se apoyó en la Sagrada Escritura para enfatizar dos criterios fundamentales:

1) Deben evitarse discrepancias entre los evangelizadores con el fin de que los indios no se escandalicen ante normas pastorales que les pueden parecer contrarias. El texto bíblico que sustenta este principio es el de 1 Cor 1,10: «os conjuro, hermanos, por el nombre de Nuestro Señor Jesucristo, que tengáis todos un mismo hablar y no haya entre vosotros cismas».

2) Es necesario dirigir y encauzar el celo misionero a tenor de lo que enseñan la Sagrada Escritura, la Iglesia, los Cánones y los Santos, con el fin de evitar caer en aquello sobre lo que previene San Pablo en Rom 10,2: «tienen celo de Dios, pero no según la prudencia». Es precisamente la Escritura el aspecto misional que nos ocupa. El objetivo de este ensayo es mostrar algunos ejemplos del papel fundamental que tuvo la Biblia en la evangelización del Nuevo Mundo particularmente durante el siglo XVI. Tres aspectos serán estudiados aquí: 1) el intento inicial de traducir los textos bíblicos a las lenguas indígenas, finalmente frustrado; 2) la importancia de la Sagrada Escritura para dilucidar las estrategias políticas y religiosas a seguir con respecto al Nuevo Mundo, ejemplarizada en la cita de Lc 14,23; 3 ) los temas bíblicos en el teatro de evangelización.

\section{Las primeras versiones de la Biblia en lenguas indígenas: un intento frustrado}

Nada más llegar a México en 1524, los primeros doce misioneros franciscanos dirigidos por fray Martín de Valencia, conocidos como los «doce apóstoles» de Nueva España, hicieron de la Biblia un elemento central de su tarea evangelizadora. Esto queda patente en sus encuentros y diálogos, a través de intérpretes, con sabios y sacerdotes aztecas tal

6 Sobre esta cuestión, véase Borges (1976; 1987) y Gómez (2000). 
como se describe en los Coloquios de fray Bernardino de Sahagún escritos hacia 1564. En el siguiente texto es notoria la identificación entre la Sagrada Escritura y la Palabra de Dios sin mención expresa a la Tradición de la Iglesia, una de las cuestiones clave en la polémica entre católicos y protestantes $^{7}$ (Morales, 2001):

Esta Sagrada Escritura, estas palabras divinas, nos mandó el gran Sacerdote [el Papa Adriano VI] que os prediquemos y enseñemos, y de su mandado las hemos traído con nosotros. Estas divinas palabras y Sagrada Escritura sobrepuja a toda la doctrina y escritura que hay en el mundo, porque es cosa divina y no humana, dada a los hombres del Hacedor de todas las cosas y Redentor del humanal linaje, solo verdadero Dios y Señor. Por ser palabras divinas son muy verdaderas y se deben creer con toda firmeza, y ninguno de todos los sabios del mundo es suficiente para argüirlas ni tacharlas 8 (Durán, 1984: 332-333).

Sahagún describe de la siguiente manera cómo fue la respuesta de los señores aztecas:

Estos mismos [los sacerdotes aztecas] tienen cargo de las historias de nuestros dioses y de la doctrina tocante a su servicio: porque nosotros no tenemos cargo, sino de las cosas de la guerra y de los tributos y de la justicia. Juntaremos a los ya dichos, y decirlos hemos lo que hemos oído de las palabras de Dios: ellos es bien que respondan y contradigan, pues que saben y los compete de oficio (Durán, 1984: 339).

Los señores aztecas aceptaron escuchar las enseñanzas de los misioneros y, según cuenta Sahagún, terminaron convirtiéndose y recibiendo el bautismo. Si bien es verdad que esta puede ser una descripción quizá demasiado simple e idealizada de una realidad probablemente mucho más compleja ${ }^{9}$ (Gil, 2006), el episodio pone de manifiesto la importancia

Como señala Morales (2001), quien encuentra en el capítulo 9 de los "Colloquios" una alusión a la visita de San Pablo al Areópago (Hch 17, 22-23), particularmente en el texto que dice: «El señor que os venimos a predicar llámese fuente de ser y vida porque él da ser y vida a todas las cosas y por su virtud vivimos. Él es el verdadero Ipalnemoani al cual vosotros llamáis. Pero nunca le habéis conocido, este nombre a sólo él conviene» (182).

8 También puede verse en Sahagún (1986). Lamentablemente, sólo se ha conservado un libro (y de éste sólo catorce capítulos de los treinta anunciados) de los cuatro previstos para la obra. Los capítulos trece y catorce son una exposición doctrinal a modo de «historia de salvación» desde la creación, pasando por el pecado original, la lucha fratricida de Caín y Abel, y la división de las lenguas en la Torre de Babel.

Sin olvidar la complejidad que entraña el hecho de que, según Dehouve (2000), en los Coloquios se encuentran dos concepciones distintas del diálogo: el diálogo didáctico 
de la Biblia en las primeras misiones evangelizadoras del Nuevo Mundo y, al mismo tiempo, la necesidad de hacerla inteligible a los indios. Lógicamente, pronto los intérpretes deben dar paso a los traductores de la Sagrada Escritura. No es corriente que sean los conquistadores quienes procuren conocer la lengua de los conquistados y, si bien el intento de los franciscanos por conocerla fue interesado (propagar la religión cristiana, la de los conquistadores), «no por ello deja de estar cargado de sentido: aunque sólo fuera para asimilar mejor al otro a uno mismo, uno empieza por asimilarse, por lo menos parcialmente, a él» (Todorov, 1998: 230). Lamentablemente, esta asimilación fue más parcial que completa dado que indios y españoles nunca estuvieron en un plano de total igualdad.

Aunque pueda parecer evidente la utilidad de traducir la Biblia a la lengua de los indios, esta empresa tuvo que afrontar muchos obstáculos. Ya los Reyes Católicos, en su Pragmática del 8 de julio de 1502, habían prohibido su traducción al castellano. Una decisión alabada por el consejero real y franciscano Alfonso de Castro, en su obra Tratado de las Herejías, publicada en París en 1534, ya que, si a todos sin distinción se les entregase la Sagrada Escritura, la palabra de Dios podría convertirse «en fuente y origen de herejía» (Höffner, 1957: 114).

Pero esto no impidió que la primera generación de misioneros en Nueva España tradujera en lenguas nativas (fundamentalmente el náhuatl y, secundariamente, el tarasco), textos de la Sagrada Escritura, especialmente las Epístolas y Evangelios para uso litúrgico ${ }^{10}$. Fue precisamente el primer obispo de México, fray Juan de Zumárraga (obispo entre 1528 y 1548), quien en su Doctrina Breve (1544), recomendara, aludiendo a Mt 11, 25, la lectura directa de la Sagrada Escritura en lenguas vulgares ${ }^{11}$, aun en

europeo, y más precisamente la disputa y, por otra parte, el diálogo ceremonial indígena. Este último representa a la vez un intercambio recíproco, es decir, un don y contra-don de palabras, y un modo eficaz de alejar la desgracia. Ninguno de los dos tipos de diálogos es gratuito, pero sus metas son distintas: la del primero, convertir y convencer (adoctrinar); la del segundo, intercambiar para restablecer la armonía en el otro. Por esta razón, la traducción del español al náhuatl, y del náhuatl al español, conservará fácilmente su forma interrogativa, pero el significado profundo cambiará al pasar de una lengua a otra.

10 Obras publicadas en México en el siglo XVI, algunas de las cuales se perdieron, pero de las que hay referencias, como la de fray Alonso de Molina, Evangelios de todo el año en lengua Mexica, obra a la que alude (Mendieta, 1973: IV, 44); la de fray Benigno Fernández, Epistolas y Evangelios en lengua misteca, o la de fray Domingo de Santa María, Doctrina cristiana y Epistolas y Evangelios en lengua Mixteca. Todas ellas de fecha desconocida.

11 Pese a que muy probablemente debido a su edad él no aprendió el náhuatl ni ninguna otra lengua indígena (Martínez Ferrer, 2006). 
contra de quienes piensan que los «idiotas» (entre ellos los indios) no están capacitados para ello:

No apruebo la opinión de los que dicen que los idiotas no leyesen en las divinas letras traducidas en la lengua que el vulgo usa, porque Jesucristo lo que quiere es que sus secretos muy largamente se divulguen; y así desearía yo, por cierto, que cualquier mujercilla leyese el Evangelio y las Epístolas de San Pablo (García Icazbalceta, 1947: 25).

Los libros completos que se tradujeron fueron Proverbios, Tobías y el Evangelio de Lucas $^{12}$. Esta versión parcial de la Biblia en Nueva España fue vigilada con las mismas leyes que en España (Alonso, 1988; Seibold, 1992), y tuvo sus oponentes. Jerónimo López, escribano de cámara en Nueva España, escribió una carta a Carlos V en 1541 en la que, entre otras cosas, denunciaba que los franciscanos permitieran el acceso de los indios a las Sagradas Escrituras. Su interpretación partía del temor al influjo luterano en España y de una visión peyorativa del indio por la que juzgaba que éste haría una mala interpretación del texto bíblico, particularmente de ciertos pasajes del Antiguo Testamento relativos a los sacrificios y la poligamia:

(...) muchos de nuestra España se habian perdido é habian levantado mil herejías por no entender la sagrada Escritura, ni ser dinos, por su malicia é soberbia, de la lumbre espiritual para entendella, e así se habian perdido é fecho perder á muchos cuanto mas estos que todavía estaban sobre el ingerto y habian de saber á él; y que mayor mal era que me decian, é de hecho era, que tenian sacada la Brivia en su lengua; que cuando viesen los sacrificios de la ley vieja, é lo de Abraham, é que así lo permitia Dios, que cómo agora se les defendia á ellos; é viesen las mujeres de David é otros, é otras cosas á que ellos eran inclinados, que cómo tomarian é aplicarian aquello á su propósito malo, é no tomarian bien alguno $(. . .)^{13}$ (García Izcabalceta, 1971: 141-154).

12 Obras hoy desconocidas, aunque se sabe que fray Luis Rodríguez, provincial franciscano de México, fue el autor de la traducción de Proverbios, como también tradujo más tarde Eclesiastés; véase (Mendieta, 1973: IV, 44). Para un listado más completo de las ediciones totales y parciales de la Biblia realizadas en este período, véase (León, 2009).

13 Casi medio siglo después, este tipo de argumentos ofrecidos por Jerónimo López, aún vigentes, fueron respondidos irónicamente por el franciscano Bernardino de Sahagún. En 1584, con motivo de la visita del nuevo comisario franciscano, Alonso Ponce, al colegio de Santa Cruz de Tlatelolco (Nueva España), se realizó una representación o sainete, probablemente organizado por Sahagún, que pretendía refutar los ataques que el colegio, formador de niños indígenas, había recibido, entre ellos el de pretender enseñar a gente tan inhábil como los indios. Pero, a la vista de sus éxitos 
De hecho, Carlos V enviará al virrey de Nueva España un decreto, fechado el 7 de junio de 1550, en el que recomienda la introducción del castellano como lengua de evangelización para evitar la dispersión de los contenidos teológicos traducidos a las lenguas indígenas ${ }^{14}$. Precisamente, fue el mal conocimiento de las lenguas indígenas por parte de muchos misioneros, causa en ocasiones de errores de doctrina motivados por fallos de trascripción cuando leían sus sermones en una lengua que no entendían, lo que provocó que el I Concilio Mexicano (1555) desaconsejara esta práctica a los misioneros y sólo permitiera la traducción de «doctrinas» o catecismos previa censura y aprobación (canon LXIX), y que el II Concilio Mexicano (1565) prohibiera la circulación entre los indígenas de obras y textos de la Sagrada Escritura traducidos a sus lenguas, salvo las aprobadas por la autoridad competente (canon XXIII) ${ }^{15}$. Por este motivo, fray Alonso de Molina publicará en México su obra Aquí comienza un vocabulario en lengua Castellana y Mexicana (1555), en cuyo prólogo, en orden a la importancia de la salvación de los indios, justifica bíblicamente la importancia de dominar la lengua de los indios:

Por esta causa, deberían los ministros de la fee y del evangelio trabajar con gran solicitud y diligencia de saber muy bien la lengua de los indios, si pretenden hacerlos buenos cristianos: pues, como dice San Pablo, escribiendo a los romanos, la fee se alcanza oyendo, y lo que se ha de oir ha de ser la palabra de Dios, y esta se ha de predicar en lengua que los oyentes entien-

educativos, sus detractores buscaron otras excusas tales como que no era necesaria tanta formación si no iban a ser sacerdotes, que podrían caer en la herejía e incluso malinterpretar la Sagrada Escritura al entender «en ella cómo los patriarcas antiguos tenían juntamente muchas mujeres, que era conforme a lo que ellos usaban, y que no querrían creer lo que ahora les predicásemos, que no puede nadie tener más que una mujer» (León-Portilla, 1987: 130-131). Tras la actuación de algunos alumnos indios hablando en latín, salió otro caracterizado de maestro, que respondía a estas objeciones en forma de denuncia: «Miente el bellaco, que por cierto que son buenos hijos y cuidadosos de la virtud y de su estudio; sino que vosotros nunca sabéis abrir la boca sino para decir mal de ellos, y cualquiera cosa que les es próspera os llega al corazón, que no queríades sino que siempre anduviesen con la carga a cuestas, ocupados en vuestro servicio» (León-Portilla, 1987: 131).

14 Sin embargo, la implantación de este decreto no tuvo mucho éxito; véase Polanco Martínez, 2000.

15 Y en relación a los sacerdotes: Ordenamos y mandamos, que todos los curas tengan Biblias, y algunas Sumas de casos de conciencia en latín, o en romance, así como la Suma de Navarro, o Defecerunt de S. Antonino, o Silvestrina, o Angélica, y algún Libro Sacramental, en que lean "Segundo Concilio de México, cap. 18", en (Lorenzana, 1769, 199). Véase también Tercer Concilio Limense, Acción III, Cap. 22, en (Vargas Ugarte, 1955: 354). Por otro lado, las Leyes de Indias mandaban en 1556 controlar los libros prohibidos por la Inquisición que llegaran a puerto (León Pinelo \& Solórzano, 1680: libro I, título 24, ley 1.7). 
dan, porque de otra manera (como lo dice el mesmo San Pablo) el que habla será tenido por bárbaro'16 (Medina, 1912: 73).

Por la misma razón el dominico fray Domingo de Santo Tomás publicará poco después, en 1560 en Valladolid, la primera Grammatica o arte de la lengua general de los indios de los reynos del Perú:

Pero, quien supiere la grande y extrema necesidad que ay en aquellas provincias de la predicación del Evangelio, y quántos millares de ánimas se han ido y van al infierno por falta de conocimiento dél y de las cosas de nuestra sancta fe católica por defecto de la lengua, sin la cual no se les puede predicar (...) (Santo Tomás, 1995: 14).

Las restricciones a las traducciones bíblicas aumentarán con la llegada de la Inquisición a Nueva España (1569), la cual se vio urgida en 1576 por el Consejo General de la Inquisición de Sevilla a prohibir el libro Eclesistés en lengua de los indios ${ }^{17}$ y toda traducción de la Sagrada Escritura a cualquier lengua vulgar, incluida la de los indios:

Con ocasión de la prohibición del libro de mano Eclesiastés en lengua india y de otro cualquiera de la Escritura Sagrada en la dicha lengua o en otra vulgar que V.S. mandó por carta de los 10 de mayo del año pasado, se recogieron en este Santo Oficio algunos libros de Epístolas y Evangelios en lenguas vulgares de los indios y después pareció que era cosa dañosa y que se disminuiría mucho la doctrina de los indios, porque sin ellos los ministros no les podrían predicar ni doctrinar ni otros de nuevo podían aprender la lengua y modo de su doctrina y así hicieron instancia para que se les volviesen y con acuerdo y parecer de los más antiguos y doctos ministros y mejores lenguas de que constó 'in scriptis' se les volvieron con orden que los quiten a los indios que los tuvieron porque también son de parecer que no los deben tener y así se los han recogido algunos cuerpos del dicho libro Eclesiastés y Horas en la dicha lengua de que no tienen necesidad (...); conque a los indios no se les permite uno de ningún libro de estos sino sólo la cartilla de la doctrina, porque en esto todos convienen ${ }^{18}$ (González Rodríguez, 1992: 109-110).

\footnotetext{
16 La cita se corresponde más bien con 1 Cor 14,11.

17 Se trata de la obra de fray Luis Rodríguez, de la que desgraciadamente se carece de más información.

18 Ya en 1559 el Consejo de la Inquisición española había publicado en Valladolid la primera lista de libros prohibidos, el Cathalogus librorum qui prohibintur mandati D. D. Ferdinandi de V aldés, la cual incluía toda versión en lengua vulgar de la Biblia o parte de ella, como versiones en lengua vulgar o latín de las Horas, versiones unas y otras que ya abundaban en Nueva España.
} 
De este modo, la Inquisición española no permitió que la Sagrada Escritura en sus versiones nativas estuviera no ya sólo en manos de los indios sino tampoco en la de sus evangelizadores o ministros. La única alternativa que ofreció fue la publicación de un sermonario y de una doctrina que fueran válidos para todos (González Rodríguez, 1997). Sin embargo, los Provinciales mexicanos de las órdenes de San Francisco, Santo Domingo y San Agustín redactaron en 1579 un memorial en el que solicitaban que esta prohibición no incluyera a los ministros. El memorial recibió el apoyo de la Inquisición local, la cual el 6 de octubre de 1581 remitió una carta al Consejo General de la Inquisición en la que se daba cumplimiento de la prohibición recibida, pero «permitiendo solamente a los ministros de los indios las epístolas y evangelios en su lengua» (Baudot, 1983: 113, nota 81; Seibold, 1992: 273). No obstante este intento aperturista, no pasó mucho tiempo para que incluso a los ministros se les prohibiera tales obras:

(...) sin embargo de lo que apuntáis en este particular, consultado con el r. Inquisidor General, ha parecido hagáis luego recoger los dichos libros de Epístolas y Evangelios que así habéis vuelto y toda otra cualquier parte de la Sagrada Escritura en lengua vulgar y no permitáis que ni ministro ni otra persona alguna le tenga ni lea y a ningún respecto pues por esta vía se podrán doctrinar y enseñar los indios (González Rodríguez, 1992: 110-111).

El Tercer Concilio Mexicano (1585) tampoco fomentará las traducciones de la Escritura a lenguas indígenas. Subraya que es tarea del obispo y de aquellos sacerdotes que asigne el predicar la palabra de Dios según lo mandado por el Concilio de Trento, interpretando la Sagrada Escritura de acuerdo al sentido de la Santa Madre Iglesia y de los Santos Padres, evitando «hacer fuerza á la Escritura apoyándose en su propia prudencia, violentándola, para fundar sentidos singulares, nuevos é inventados a su arbitrio, ni profieran cosa alguna que sea agena de la Iglesia o de sus doctores» (Galván Rivera, 1859: libro primero, título I, $2)^{19}$. Pero, obviamente, nada dice de traducirla a las lenguas indígenas. Más aún, dicho Concilio establece que ningún libro puede imprimirse sin

19 Sigo la edición en latín y castellano del III Concilio Mexicano realizada por Galván Rivera (1859). El II Concilio Provincial de Lima (1567), en su parte primera, capítulo 77, dictaminaba seguir «siempre en la exposición de la Escriptura el sentido y declaración de los santos padres», y animaba a «que la Palabra de Dios se predique a menudo al pueblo» (parte primera, 78). Eso sí, recomendaba que los predicadores «huyan de reprehender en público y manifiestamente a los prelados y gobernadores» (parte primera, 79). ¡Antonio de Montesinos no hubiera podido ejercer la denuncia profética en sus famosos sermones! 
la licencia del obispo, quien debe a su vez examinar previamente aquellos libros de «religión» en lengua nativa (libro primero, título I, 7).

Fuera de Nueva España, la situación de las Sagradas Escrituras no fue distinta. En el Virreinato del Perú, tan pronto se instauró la Inquisición a instancias del virrey Toledo en 1568, se promulgó un edicto en el que, entre otras cosas, se instaba a denunciar, a la par, a quienes tuvieran libros protestantes, el Corán e incluso traducciones de la Biblia al castellano:

(...) y si saben que alguna o algunas personas hayan tenido y tengan libros de la secta y opiniones del dicho Martín Lutero y sus secuaces o el alcorán y otros libros de la secta de Mahoma o biblias en romance o otros cualesquiera libros de los reprobados por las censuras y catálogos dados y publicados por el santo oficio de la Inquisición (...) (Medina, 1956: 25).

La prohibición de traducir las Sagradas Escrituras a lenguas vernáculas, incluidas las de los indios, se extendió, lógicamente, a todos los Reinos de España y no fue derogada hasta que en 1782 el inquisidor general Felipe Beltrán levantara la prohibición con la condición de que las nuevas traducciones fueran aprobadas por la Silla Apostólica o producidas por autores católicos con anotaciones de los Santos Padres o doctores católicos que evitaran desviaciones doctrinales.

Esta prohibición no sólo impidió que los indios pudieran comprender mejor el sentido de las Escrituras en su propia lengua; impidió también que tuvieran un acceso directo a aquellos textos bíblicos que pudieran tener un sentido liberador para ellos. Más aún, indirectamente significaba que su propia lengua no tenía ningún valor como transmisora de las palabras sagradas, ni siquiera de las palabras sagradas de sus conquistadores.

No obstante este gravísimo freno a las traducciones de la Biblia, las Sagradas Escrituras no dejaron por ello de ser fundamentales en la labor evangelizadora del Nuevo Mundo, aunque por otros derroteros distintos al de la traducción.

\section{Lc 14,23, una cita controvertida: ¿Evangelización pacífica o forzada?}

Que la Biblia no pudiera traducirse a las lenguas vernáculas, dificultando así su comprensión para la población indígena, no significó, ni mucho menos, que desapareciera de la vida religiosa, e incluso política, de la época. La Biblia fue una fuente vital para legitimar una serie de acciones políticas y misioneras que incidían directamente en los indios del 
Nuevo Mundo. De su acertada o incorrecta utilización podían depender graves decisiones que afectaban a las vidas y costumbres de los indios.

Ya en 1540, desde la provincia de Mixteca, el dominico fray Domingo de Betanzos reconocía y lamentaba que:

Toda la manera de convertir a estas gentes desde el principio hasta agora, siempre ha sido más violenta que voluntaria, lo qual todo es contra la doctrina y evangelio de nuestro Redentor; y por eso, siempre estamos sospechosos de la cristiandad destos mayores, por no ser firmado en ellos la fe por amor; y por eso nunca se han desarraigado de sus ídolos totalmente ni de su voluntad; porque si alguno los ha dexado así, más por fuerza, quitándoselos contra su voluntad (Las Casas, 1990: XXXVII).

La violencia ejercida en no pocas ocasiones contra los indios con el objetivo de forzar sus conversiones, además de para lograr su conquista y sujeción, propició serios debates auspiciados incluso por la Corona española. Uno de los más relevantes fue el que sostuvieron el dominico fray Bartolomé de Las Casas y el humanista y cronista del Emperador, Juan Ginés de Sepúlveda (1490-1570), durante la conocida como la "Gran Controversia", que tuvo lugar en Valladolid en 1550 y 1551.

Su objetivo era decidir sobre lo que sería la regla justa a aplicar para hacer eficaz la propagación de la fe en las Indias, tras el fracaso de las Leyes Nuevas de 1542, que prohibían la esclavitud de los indios y la encomienda hereditaria. Ambos litigantes pleitearon eruditamente sobre diversas cuestiones relativas al derecho de conquista y a la forma de evangelización utilizando con profusión la Escritura para defender sus $\operatorname{argumentos}^{20}$. No se llegó a ninguna conclusión efectiva, pero finalmente Las Casas consiguió que los escritos donde Sepúlveda defendía sus argumentos fueran prohibidos.

De entre todas las citas bíblicas que se esgrimieron, hay una que suscitó en la época bastante controversia porque algunos vieron en ella la justificación escriturística para la conversión forzosa de los indios. En ella fijaremos nuestra atención como un ejemplo claro de la importancia que tuvo la Sagrada Escritura para dilucidar cuál debía ser la estrategia misionera adecuada. Se trata de Lc 14,23, perteneciente a la parábola del hombre rico a cuya fiesta no acuden los invitados, razón por la que envía a su criado a buscar por los caminos a pobres y lisiados para invitarlos al banquete: «El amo dijo al criado: Sal a los caminos y veredas y oblígalos a entrar hasta que se llene mi casa» (Vulgata: et ait dominus servo exi in vias et sepes et conpelle intrare ut impleatur domus mea).

20 Para una comparativa de cómo ambos litigantes utilizaron la Biblia para sostener sus argumentos, véase el estudio de León (2008). 
Agustín de Hipona, que había fracasado en su discusión con los donatistas, justificaba en su vejez el empleo de la violencia contra los herejes apelando a Lc 14,23. Fue el primero, interpretando erróneamente el compelle intrare, en encontrar en estas palabras el fundamento bíblico de la licitud del empleo de medidas de violencia contra los herejes ${ }^{21}$, si bien rechazaba la pena de muerte.

La interpretación de Agustín queda reflejada en el siguiente fragmento de la carta de Agustín a Vicente rogatista, escrita en el año 408 d.C., el cual será utilizado por Juan Ginés de Sepúlveda para defender sus argumentos. Agustín entiende que de la conversión, aunque en ocasiones pueda ser forzada incluso por el mismo Dios, se obtiene un bien mayor que de vivir en el «erron»:

Piensas tú que nadie debe ser obligado a ser justo, mientras lees que el Padre de familias dijo a sus siervos: $A$ todos los que hallares, oblígalos a entrar; mientras lees que Saulo, el que después fue Pablo, fue compelido por una imponente violencia de Cristo, que le obligaba a conocer y retener la verdad. A no ser que pienses que los hombres aprecian más el dinero o cualquiera de sus posesiones que esta luz que se recibe por los ojos. Derribado Pablo por la celeste voz, perdió esta luz y no la recuperó sino cuando se incorporó a la santa Iglesia. Tú piensas que no se puede hacer fuerza al hombre para que se libre de la ruina del error. Pero Dios, a quien nadie vence en amar, nos la hace, como ves en los ejemplos dichos (Agustín, 1951: 300).

\subsection{Juan Ginés de Sepúlveda}

Los argumentos de Juan Ginés de Sepúlveda se recogen en su obra Democrates Secundus o De las justas causas de la guerra contra los Indios, cuya primera redacción escribió en 1545, y que experimentó retoques y añadidos sucesivos ${ }^{22}$. Por su parte, la respuesta de Bartolomé de Las Casas a

21 Al respecto, véase Agustín (1951), Contra Gaudemtium Donatistam, I, 25-28 y Carta a Vicente rogatista, cap. II, 5, 10.

22 Como ya se ha dicho, la intervención y presiones de Las Casas lograron que el Democrates Secundus no fuera publicado. En cambio, en 1550 sí fue publicado en Roma una especie de resumen del mismo titulado Apología del libro sobre las causas de la guerra. Como señala Losada (1976), Las Casas no llegó a conocer el Democrates Secundus, pero sí la Apología de Sepúlveda. El Democrates Secundus no verá la luz, aunque de manera incompleta, hasta 1892, cuando Marcelino Menéndez y Pelayo lo imprimió en el Boletín de la Academia de la Historia. El jesuita José de Acosta se hizo eco, sin mencionar su nombre, del rechazo que obtuvo la obra de Ginés de Sepúlveda por parte de las Universidades de Alcalá y Salamanca: «las insignes Universidades de Alcalá y Salamanca, que, según he oído decir, han condenado y proscrito un libro de cierto autor contrario a los indios, y aun del mismo Consejo de Indias» (Acosta, 1984: II, 4). 
estos argumentos se recoge en su monumental obra titulada Contra los perseguidores y calumniadores de los pueblos del Nuevo Mundo descubierto en el Océano (1550-1551), más conocida como Apología contra Ginés de Sepúlveda.

El célebre humanista se servirá de Lc 14,23 para justificar que la guerra justa contra los indios facilitaba la propagación de la religión cristiana entre los indios. La guerra contra los infieles, en su opinión, es justa por la razón de que posibilita la propagación de la religión cristiana y las tareas de los misioneros: «atañe al cumplimiento de un precepto evangélico de Cristo y se dirige a atraer por el camino más próximo y corto a la luz de la verdad, a una infinita multitud de hombres errante entre perniciosas tinieblas» (Ginés de Sepúlveda, 1984: f. 33).

En opinión de Ginés de Sepúlveda (1984), el «oblígalos a entrar» (compelle intrare) del v. 23 no se limita a una violencia «espiritual de exhortaciones y milagros», sino que puede conllevar una violencia corporal $^{23}$. Se trata de una violencia no para obligar a hacer el bien, algo que entiende no puede hacerse contra la voluntad de nadie, sino para suprimir los impedimentos que se opongan a la predicación del Evangelio. Así interpreta este versículo bíblico, citando, como se ha dicho, a Agustín:

Y en verdad que cuanto más se va cumpliendo esto [se refiere al Sal 71,11], tanto más va creciendo el poder de la Iglesia, no sólo para invitar, sino también para obligar al bien, y esto quería significar el Señor, pues aunque tenía gran potestad prefirió, sin embargo, encomendar primero la humildad. Y para confirmar San Agustín esta opinión con la doctrina evangélica, añadió: Cristo mostró esto con bastante evidencia en aquella parábola del convite, cuando [el padre de familias] envió a llamar a los invitados y al no querer venir dijo al siervo: "Sal pronto a las ciudades y a las calles y a los arrabales de la ciudad e introduce aqui a los pobres y débiles, a los ciegos y cojos", y dijo el siervo al señor: "Se ha hecho como has mandado y todavia hay lugar"; y dijo el señor al siervo: "Sal a los caminos y cercados y obliga [a todos] a entrar hasta que se llene mi casa". Repara abora, dice, cómo de los primeros que habian acudido se dijo: introdúcelos, y de los últimos se dijo: oblígalos. Asi se representaron los comienzos de la Iglesia todavía creciente y su progreso

23 Como así se expresa Ginés de Sepúlveda (1984), según el testimonio del propio Las Casas en su "Controversia entre Las Casas y Ginés de Sepúlveda", en su respuesta a la segunda objeción de las doce que coligió del sumario que hizo Domingo de Soto de la apología de Las Casas contra él (ff. 19v-20). Ciertamente, el verbo griego original de Lc 14,23, anankazein, significa «obligar», aunque en Mc 6,45 y Mt 14,22 puede tener un sentido más suave, próximo al de «urgir» o «apremiar». En español, el verbo «compeler» no da lugar a dudas. Según el Diccionario de la Real Academia de la Lengua Española, significa: «Obligar a alguien, con fuerza o por autoridad, a que haga lo que no quiere». 
en que [los gentiles] habian de ser compelidos por la fuerza $a^{24}$. En consecuencia, el mismo San Agustín atestigua que es tan propio del óptimo como del justísimo príncipe el establecer una ley contra los paganos y sus sacrificios, sancionándose con la pena capital y la confiscación de bienes, no sólo para los que perpetran sacrificios impíos, sino también para los gobernadores de las provincias que descuidasen el castigo del crimen ${ }^{25}$ (Ginés de Sepúlveda, 1984: f. 35v-36).

Más adelante, volverá a la cita lucana poniéndola en relación con Dt 20, 15 (cita originalmente relativa a las campañas de conquista de la Tierra Prometida pero que Ginés de Sepúlveda descontextualiza), subrayando que se refiere más a los paganos (en este caso, los indios) que a los herejes:

(...) este pasaje del Evangelio [Lc 14,15-24] conviene a los paganos aún mucho más que a los herejes, pues el convite no tanto estaba preparado para los herejes, que entonces no existían, como para los judíos y paganos (...) Finalmente, en estos tiempos también los paganos llamados lejos de la ciudad, desde los caminos y los cercados, esto es, desde los lugares más remotos [alusión a Dt 20,15], son impelidos por mandato divino a entrar en el banquete de Cristo, pues en el caso de los herejes, se debe aplicar la palabra "volver" más bien que "entrar", cuando de nuevo son llamados a la fe católica. A ambos, no obstante, convienen los preceptos de San Agustín que dimanan de la auténtica fuente, esto es, de la caridad cristiana para con el prójimo (Ginés de Sepúlveda, 1984: f. 39).

De esta manera, Ginés de Sepúlveda reinterpreta al propio Agustín, cuyo escrito alude expresamente a los herejes, para dar a entender que la obligación de compeler se extiende también a los gentiles o paganos, que, en este caso, no son otros que los indios. El indio, así, además de un «otro» inferior y conquistado, es también un «otro» pagano, y, consecuentemente, por su propio bien («la caridad cristiana para con el prójimo»), puede ser forzado a la conversión al cristianismo.

\footnotetext{
24 Aquí el autor inserta a Agustín (1951), Carta a Vicente rogatista, cap. II, 5.

25 Conviene señalar que, en este sentido, Ginés de Sepúlveda no parece forzar la interpretación que hace Agustín de este texto. Como apunta un prestigioso comentarista del Evangelio de Lucas, ajeno a la polémica entre Sepúlveda y Las Casas: «Desde los tiempos de san Agustín (Contra Gaud. Don. I,25-28 = CSEL 53,226-227), se ha interpretado frecuentemente el verbo anankazein en el sentido de ejercer fuerza física para convertir a la gente; de aquí que se haya considerado a san Agustín como inspirador espiritual de la Inquisición» (Fitzmyer, 1987: 621). De igual manera, Schmid, 1968: 355.
} 


\subsection{Bartolomé de Las Casas}

Por el contrario, Las Casas critica duramente este argumento, fundamentalmente sobre la base de que el Evangelio debe predicarse con el ejemplo y la virtud y no acompañado de las armas, las cuales provocan un efecto muy negativo y desfavorable contra la religión cristiana en los indios. La hermenéutica bíblica de Las Casas tiene en todo momento como centro al «otro», al indio víctima de los abusos de los españoles ${ }^{26}$. Desde esta clave hermenéutica el dominico arremete contra la interpretación que hace Ginés de Sepúlveda de Lc 14,23, al que acusa de forzar el auténtico sentido literal de la cita. Las Casas también se apoyará en Agustín, pero no en la interpretación particular que éste hace de la cita lucana, sino en su clave hermenéutica para interpretar, en general, los textos bíblicos:

Además. He aquí un argumento contra el famoso Doctor Sepúlveda y su pertinacia: el sentido literal de cualquier pasaje de la Escritura, que, de acuerdo con San Agustín y Santo Tomás, es la única base para su argumento, es aquel que quiere que le demos su autor, esto es, el Espíritu Santo. Ahora bien, en aquellas palabras de la parábola: "Fuérzales a entrar" (compelle eos intrare), Cristo da a entender que Él, directamente, por Sí mismo ${ }^{27}$, o por los ángeles, o por los hombres, puede mover intelectualmente, atraer y, en cierto sentido, compeler hacia Sí, por medio de milagros visibles e invisibles, a aquellos que no conocen la verdad, sin ejercer, sin embargo, ninguna coacción de la voluntad. Tal es el sentido literal. Así pues, con esta parábola, Cristo dio a entender que debía utilizarse no la violencia exterior, sino la violencia persuasiva (Las Casas, 1989: f. 188).

A tenor de esto, según Las Casas, el sentido literal de Lc 14, 23 indica que únicamente es Cristo quien puede compeler, sin coacción alguna, a los gentiles a que se conviertan. Poco después, el dominico explica, apoyándose en los casos de Jeremías (Jr 23, 29) y Pablo (2 Tim 4, 2; Tit 2,15), el sentido de esta «violencia persuasiva»: «Esto equivale a mover los corazones de los hombres, infundiendo en las potencias del alma miedo o tristeza, o afligiendo del exterior al cuerpo con enfermedades o sufrimientos, iluminando la propia alma con la luz del Espíritu Santo» (Las Casas, 1989: f. 188v).

26 Para un estudio detallado del uso de la Biblia en Las Casas, véanse: Esponera Cerdán (1990), y, especialmente, Frades (1997).

27 En el f. 190 cita Las Casas Mt 21,12 (la expulsión de los vendedores del templo) y Jn 18,6 (la reacción por parte de los que acompañaban a Judas a prender a Jesús de retroceder y caer en tierra ante el autoritativo «Yo soy» de Jesús) como ejemplos de cómo Cristo, por su poder divino, cambió las mentes de los hombres. 
Las Casas hace acopio de citas, tanto del Antiguo ${ }^{28}$ como del Nuevo Testamento $^{29}$ para justificar que el comportamiento de los predicadores cristianos, imitando al de Cristo, debe ser intachable, y el trato a los paganos blando y caritativo, ya que, de lo contrario, se difama el nombre de Cristo por culpa de los cristianos que lo convertirían, a los ojos de los indios, en el más impío de los dioses. Esto es lo que precisamente hacen, en opinión del dominico, los misioneros españoles cuando predican acompañados de soldados ${ }^{30}$. Lo expresa de forma clara y dura:

Además, cuando Cristo envió a sus discípulos a predicar el evangelio; ¿con qué espadas y lombardas los envió? Oigamos la orden que Cristo da a los apóstoles diciéndoles: "Y en vuestro camino predicad diciendo: El reino de

28 Particularmente citas sapienciales: Sap 8,1; Eclo 6,5; Prov 15,1 (f. 191).

29 Por orden de aparición: Jn 13,15; Mt 11,29; Jn 15,12; Rom 13,10; Gal 6,10; 1 Cor 10,31-32; Fil 2,15; 4,5; Tit 2,7; 1 Ped 2,12; Lc 9,2-6; Mt 10,16 (ff. 199 y 200).

30 En el tratado de Las Casas sobre la controversia, Ginés de Sepúlveda (1984) matiza que «los soldados no son para convertir ni predicar: sino para subjectar a los bárbaros y allanar y assegurar el camino de la predicación. La qual han de hazer frayles y clerigos de buena vida, doctrina, y exemplo» (f. 25). En este punto, el jesuita José de Acosta, sin mencionarlo, se distancia de Las Casas, y, aunque se opone a los argumentos de Ginés de Sepúlveda a favor de la guerra justa, en cambio, reconoce la bondad de que los misioneros puedan ser protegidos por soldados. Así, en (Acosta, 1984: II, 12), afirma lo siguiente: "Ambos es necesario que vayan juntos, soldado y sacerdote, como lo muestra no sólo la razón, sino la experiencia comprobada con largo uso”. El II Concilio Provincial de Lima (1567), en su parte segunda, capítulo 21, y el III Concilio Provincial de Lima (1583), en el capítulo dieciséis de su tercera acción, habían prohibido a los sacerdotes y clérigos llevar armas (indicio de que algunos solían llevarlas). Además, este último concilio prohibía, bajo pena de excomunión, que los clérigos fueran a las guerras contra indios sin especial licencia, dado que «va en ello la hazienda y libertad y vidas de tantos hombres» (acción segunda, capítulo siete). De modo similar, el III Concilio Provincial de México (1585), libro V, título VIII,1. Todavía en el siglo XVII, aunque con un talante muy distinto al de Acosta, el franciscano (Sosa, 1848) defenderá la necesidad de protección militar. El jesuita (Pérez de Ribas, 1992: libro II, capítulo XII) sostendrá la utilidad de los presidios de soldados en zonas fronterizas para proteger a los mismos indios de los ataques de otros indios y para evitar en lo posible las profanaciones de las cosas sagradas y que los indios convertidos fueran molestados por los infieles. Se apoyará en diversos episodios bíblicos, especialmente en el celo violento mostrado por Matatías (1 Mac 2,23-24), en la alianza de Judas Macabeo con los romanos (1 Mac 8,17-32) y en el mismo ejemplo de Pablo que defiende el respeto a la autoridad civil (Rom 13,1-4) y acude al César para pedir justicia (Hch 25,1-12). Por otra parte, las Leyes de Indias se muestran taxativas al prohibir la guerra como método evangelizador: «que no se puede hacer ni haga guerra á los Indios de ninguna Provincia para que recivan la Santa Fé Catolica» (León Pinelo \& Solórzano, 1680: libro III, título 4, ley 9). En opinión de (Gómez Canedo, 1976: 34): «Los misioneros experimentados juzgaron que las escoltas y los presidios eran beneficiosos, no sólo para la defensa y policía de las misiones sino como ayuda en el establecimiento de éstas y en la educación de los indios». 
Dios se acerca. Curad a los enfermos, resucitad a los muertos, limpiad a los leprosos, arrojad a los demonios; gratis lo recibís, dadlo gratis 31 ". Ahora bien, nuestros predicadores, rodeados de una caterva de soldados, o más bien de ladrones, ¿con qué cara dirán a los indios: "A mano tenéis el reino de los cielos"? Más bien, dirán: "A mano tenéis el reino de los infiernos, tanto para nosotros que os mataremos y os saquearemos vuestras moradas, como también para vosotros que exhalaréis vuestro espíritu sin la fe y la gracia de los sacramentos" (Las Casas, 1989: f. 200 y v).

El dominico culmina su Apología con una llamada a la evangelización pacífica de los indios ${ }^{32}$, a los que describe de manera idealizada como las gentes más aptas para recibir el evangelio y a los que considera «hermanos», lo que implica que Las Casas ve al indio no como un «otro» distinto e inferior, sino como un igual:

Los indios son nuestros hermanos y Cristo ha dado su vida por ellos. ¿Por qué los perseguimos con tan inhumana crueldad, no habiendo ellos merecido semejante trato? Lo pasado, puesto que lo que dejó de hacerse ya no tiene arreglo, debe ser atribuido a nuestra debilidad, a condición de que se haga restitución de los bienes injustamente arrebatados ${ }^{33}$. Finalmente, esté lejos de nosotros toda crueldad y aparato bélico más propio de los mahometanos que de los cristianos. Sean enviados a los indios heraldos íntegros, cuya conducta dé testimonio de Jesucristo y transmita el espíritu de San Pedro y San Pablo. Estoy convencido de que los indios abrazarán la doctrina del evangelio, pues no son necios ni bárbaros sino que tienen una innata sinceridad y son sencillos, modestos, mansos y, finalmente tales que yo no sé que exista otro pueblo más dispuesto que ellos para recibir el evangelio. Una vez que lo han abrazado, es de admirar con qué piedad, ardor, fe y caridad cumplen los preceptos de Cristo y veneran los sacramentos; pues son dóciles e ingeniosos y en la habilidad y dotes naturales superan a la mayor parte de las gentes del mundo conocido (Las Casas, 1989: ff. $252 \mathrm{v}-253)^{34}$.

31 La alusión es a Mt 10,7-8, pero la frase «el reino de Dios se acerca» se corresponde mejor con Mc 1,15 que con Mt 10,7 (o Mt 3,2).

32 Es el tema central de (Las Casas, 1990). También aparece en (Las Casas, 1994: prólogo; I, 22 y 25).

33 En su tratado Las doce dudas Las Casas defenderá que se impone una restitución global y solidaria de todos los males causados en el Perú por los españoles contra todo derecho (Osuna, 1975).

34 Por otra parte, (Las Casas, 1994) considera un milagro de Dios la conversión de los indios al cristianismo a pesar del antitestimonio mostrado por los españoles. Tal es el maltrato de los españoles y tal la mansedumbre de los indios que Las Casas los identificará con Cristo. Sobre esta identificación, véase a Castillo Mattasoglio (1993: 233-234). 


\subsection{Luis de León}

Al margen de la polémica entre Ginés de Sepúlveda y Las Casas, esta parábola lucana siguió siendo relevante en el tratamiento de la cuestión sobre el empleo de la fuerza en la conversión de los «infieles». Sin haber estado en las Indias, el gran humanista Fray Luis de León se preguntará, en su poco conocido Tratado sobre la fe (1567-1569), acerca de la obligatoriedad a los infieles de recibir la fe mediante la fuerza y las armas ${ }^{35}$. Comienza ofreciendo la interpretación de Juan Duns Escoto de dicha parábola, por la que éste se muestra favorable al derecho de los príncipes cristianos a obligar a aceptar la fe a los infieles a ellos sometidos ${ }^{36}$. Pero, tras un breve repaso de las opiniones de otros autores (entre los que no están Ginés de Sepúlveda y Las Casas), concluirá que «forzar a los infieles, ya sean súbditos de cristianos o libres, a abrazar la fe va contra la ley natural y la divina $)^{37}$ (Moreno \& Martos, 1999: 7). Vale la pena reproducir algunos de los principales argumentos bíblicos que utiliza para llegar a esta conclusión:

Por último, la Iglesia no tiene autoridad sobre los infieles según dice el Apóstol: ¿No es a los de dentro a los que vosotros juzgáis? Porque a los de fuera los juzgará Dios [1 Cor 5,12]. Así pues, la Iglesia no puede obligar a los infieles a aceptar la fe. La consecuencia es evidente, puesto que tal coacción corresponde a la fuerza y autoridad coactiva. Esto mismo lo prueban diversos testimonios de la Escritura y en primer lugar dice Cristo: Id por todo el mundo y predicad el Evangelio a toda criatura [Mc 16,15]. Y también: Enseñad a todas las gentes [Mt 28,19]. No dice forzad sino enseñad, y esto no se hace por la fuerza de las armas, sino con la oración. También en el Evangelio de San Mateo, cuando Cristo envió a sus apóstoles a predicar el Evangelio, les dijo: Mirad que os envío como ovejas entre lobos [Mt 10,16]. Y les mandó que no llevaran consigo ni bastón ni espada. Y también les mandó que cuando entraran en los pueblos y ciudades anunciaran inmediatamente la paz y curaran a todos los enfermos $y$, finalmente, que no hicieran nada sino con gran calma y afabilidad (Moreno \& Martos, 1999: 9).

35 Puede verse la traducción del texto de fray Luis de León relativo a esta cuestión en (Moreno \& Martos, 1999: 3-21).

36 Esto puede verse en la obra de Juan Duns Escoto, Comentario a los cuatro libros de la Sentencia de Pedro Lombardo, 4, última cuestión, según Moreno \& Martos (1999: pág. 3, nota 1).

37 Sin embargo, hay una cierta contradicción en el agustino al considerar que se puede obligar a los infieles a cumplir la ley natural, lo que no significa que deban ser obligados a aceptar el cristianismo, ya que pueden «continuar con el culto a un único Dios». Sobre estos aspectos contradictorios consultar Yates (2008). 
Tras otras alusiones bíblicas (particularmente a Mt 10,14-15 y Lc 9,54), fray Luis de León vuelve a la parábola lucana, la cual interpreta no como un mandato del Señor referente a la forma de evangelizar, sino como una profecía de lo que le sucederá a la Iglesia en su tarea misionera: los primeros destinatarios fueron los judíos que rechazarán la fe cristiana, por lo que fueron invitados los cojos y débiles, y, finalmente, al quedar todavía sitio, los españoles fueron al Nuevo Mundo impulsados por la codicia y forzando a los indios a convertirse a la fe cristiana contra su voluntad. Lo describe de la siguiente manera:

Y, como ellos [los judíos] no quisieron creer, los apóstoles invitaron a la fe a los cojos, débiles e ignorantes gentiles que iban por el foro y las plazas y los introdujeron en la Iglesia. Finalmente, como quedaba todavía un puesto vacío en el banquete y faltaba algo para el número elegido, nuestros españoles llegaron al Nuevo Mundo (a las Indias) impulsados por la codicia de oro y la avaricia y arrastraron a la Iglesia a cuantos infieles encontraron ciegos de la verdadera fe y extraviados, aunque no quisieran y se resistieran. Y como Cristo había previsto que sucedería esto y había explicado en aquella parábola los inicios, el desarrollo y la consumación de la Iglesia, utilizando una comparación adecuada de un padre de familia y un banquete, no dictó ningún mandato, sino una profecía de lo que habría de suceder. Por esto no se puede tomar ningún argumento eficaz de esta parábola en contra de nuestra opinión (Moreno \& Martos, 1999: 12-13).

Sin embargo, años después, en su Exposición del profeta Abdías (1589) donde comenta la versión mateana de dicha parábola (Mt 22, 1-14), el agustino parece cambiar ligeramente de opinión. Quizá apremiado por lo que (Moreno \& Martos, 1999: XXX) llaman su «obsesión escatológica indiana», según la cual la conversión al cristianismo de los indios sería el anuncio y paso previo al fin del mundo, el agustino parece justificar cierta violencia en la conquista y predicación sobre la base de una imagen de los indios más negativa, que los describe como salvajes:

Finalmente, con la salida de la ciudad y la entrada a la fuerza en el salón de banquetes de todos los que estaban en el campo, anunció Cristo que en los últimos momentos del mundo habría algunos que saldrían del mundo romano y avanzarían más allá de los límites conocidos del universo, tenidos desde siempre por los últimos, descubriendo otro mundo habitado por hombres fieros y completamente salvajes, a los que estos hombres harían entrar en la Iglesia en parte a la fuerza, en parte mediante la instrucción, y los convertirían poco a poco del salvajismo y la inhumanidad y la adoración tan vana de los ídolos a la civilización y a una forma de vida más hu- 
mana, y finalmente harían que quisieran participar en el banquete celeste (Moreno \& Martos, 1999: 48-49) ${ }^{38}$.

El agustino ha pasado de una interpretación profética de la parábola lucana, valiente por lo que tiene de clara denuncia de la violencia y avaricia de los españoles contra los indios, a una interpretación escatológica que atenúa la denuncia por la urgencia de la conversión de los indios ante un hipotético próximo final de los tiempos.

\subsection{José de Acosta}

Fray Luis de León no será el único en mantener una cierta ambigüedad a la hora de interpretar esta cita lucana. El jesuita José de Acosta también. Su obra De Procuranda Indorum Salute, publicada en 1588, recoge las principales orientaciones del II Concilio Límense (1567), asume la problemática de la primera Congregación Provincial de la Compañía de Jesús en el Perú (1576) y prepara las resoluciones del III Concilio Límense (1582-1583), el cual adapta las conclusiones del Concilio de Trento (1545-1563) a la situación peruana.

Además, aporta una serie de principios o convicciones que serán fundamentales en la evangelización del continente, tales como que Dios llama a los indios al Evangelio y la no licitud de la guerra contra los indios salvo en caso de injurias, ya que los indios son libres por naturaleza y merecen respeto aún en su barbarie e infidelidad (Acosta, 1984). Acosta señala una serie de principios básicos que deben regir todos los tipos de misión, entendida ésta como un método nuevo y adaptado de evangelización: la ausencia de todo tipo de violencia, la integridad de vida como concordancia entre fe y vida, y el conocimiento de lenguas y culturas indígenas, para poder evangelizar en el idioma vernáculo (Sievernich, $2007)^{39}$.

No obstante estos principios, Acosta llega a justificar la función pedagógica de cierta violencia, pese a que reconoce lo contradictorio de la predicación del Evangelio con la violencia. Esta forma pedagógica la

\footnotetext{
38 No obstante, en el mismo comentario a Abdías, fray Luis de León no perderá ocasión de denunciar los excesos de los españoles con los indios. Comentando Is 18,1, interpreta que el «iAy, tierra de címbalos de alas!» quiere decir «iAy de España, aunque destaque por sus barcos!» porque «si alguien examina su comportamiento [el de los españoles] avaro, inhumano y completamente cruel con los indios, comprenderá que algún gran mal les tiene reservado y destinado la divinidad por estas cosas».

39 Sobre el influjo de Acosta en la evangelización del continente americano, véase también Seibold (1993: 63-76). y sobre el estilo educativo de Acosta ver el estudio de Arroyo (1993).
} 
justifica en base a la condición infantil y a veces servil de los indios, en todo caso hombres libres, quienes necesitan en ocasiones del castigo físico para ser educados e impelidos a convertirse. Se apoyará también en diversas citas veterotestamentarias de índole sapiencial relativas a la educación de los hijos y a la corrección de los siervos:

Es indudable, y lo confirma la experiencia, que la índole de los bárbaros es servil, y si no se hace uso del miedo y se les obliga con fuerza como a niños, rehusan obedecer. ¿Qué hacer, pues? ¿Solamente los varones de noble ingenio han de tener esperanza de salvación? No habrá que poner a los niños un ayo en Jesucristo? Cierto, hay que hacerlo; hay que procurar para ellos un trato más cauto y vigilante, hay que usar del azote, solamente en Cristo; hay que hacerles fuerza en el Señor para que entren al banquete [Lc 14,23]. Porque no se han de buscar sus cosas, sino a ellos. Dice el sabio: «La vara y la corrección dan la sabiduría, y el niño que es dejado a su capricho avergüenza a su madre» [Prov 29,15]. Y más abajo: «Al esclavo no lo puedes instruir con palabras, porque entiende lo que les dices, pero tiene a menos responden [ Prov 29,19]. Y en otro lugar: «Al asno la cebada, la vara y la carga; el pan, la disciplina y el trabajo, al esclavo; con la disciplina trabaja y está buscando el descanso; levanta la mano de encima de él y buscará la libertad» [Eclo 33,25-26] (...) Y aunque estos preceptos se refieren al gobierno de los esclavos, (...) no menos conviene a los indios, que aunque por su condición son libres, pero en sus costumbres y naturaleza son como siervos (Acosta, 1984: I,7).

Acosta reconoce que Evangelio y violencia son dispares, pero entiende que la realidad de su época en lo referente a la conversión de los indios ha estado marcada por una confusa mezcla de violencia y predicación evangélica que sólo se puede comprender desde la sabiduría divina, lo que sostiene apoyándose en Lc 14,15-24:

Es difícil enseñar el modo de predicar el Evangelio a los indios. Dos cosas entre sí tan dispares como son evangelio y guerra, difusión del evangelio de la paz y extensión de la espada de la guerra, nuestra edad ha hallado modo, de juntarlas en uno, y aun de hacerlas depender una de otra. (...) Pues conciliar cosas entre sí tan contrarias como son violencia y libertad, y hacer que la inteligencia halle camino para unirlas y la industriosa caridad las torne coherentes, es obra que supera mis fuerzas e ingenio. Pero el Señor, que preparó en el evangelio aquellas bodas famosas y reales [Lc 14,15-24] y ahora no halla en estas tierras más que convidados sucios y harapientos y, por decirlo en una palabra, bárbaros, enseñará a sus siervos, conforme a la divina sabiduría, el modo con que habrán de proceder para no admitir al banquete los indignos, ni tampoco rechazar por bajos y rotos a los que la 
divina liberalidad llamó, aunque haya que hacerles alguna fuerza conveniente, y empujarles con alguna voluntaria violencia (Acosta, 1984: II, 1).

No obstante, pese a esta ambigüedad, Acosta no será, en líneas generales y como ya se ha apuntado, partidario de la violencia como medio coercitivo para conseguir la conversión de los indios, a quienes siempre considerará dignos de la salvación divina, aunque a veces proyecta sobre ellos una visión excesivamente paternalista como si de niños se tratase.

\subsection{Jerónimo de Mendieta}

Unos años más tarde, en 1604, fecha de la publicación de su Historia Eclesiástica Indiana, el franciscano Jerónimo de Mendieta, imbuido todavía de la mentalidad apocalíptica y milenarista propia de la primera generación de misioneros franciscanos que llegó a Nueva España (conocida como los “doce apóstoles”), interpreta la parábola de Lc 14,15-24 escatológicamente como antesala del fin de los tiempos, de modo similar a como hiciera fray Luis de León, si bien el franciscano no alude al agustino.

Desde esta interpretación, Mendieta considera que las tres salidas del siervo mencionadas en la parábola se corresponden, respectivamente, con la llamada a la conversión a los judíos, moros y gentiles, y que corresponde a los reyes de España, por el mandato del Papa, la tarea de evangelización de todas las gentes, preámbulo del final de los tiempos:

Tenemos, pues, de aquí, que la parábola propuesta en el santo Evangelio, del siervo enviado á llamar gente para la cena del Señor, á la letra se verifica en el rey de España, que á la hora de la cena, conviene á saber, en estos últimos tiempos, muy cercanos al fin del mundo, se le ha dado especialmente el cargo de hacer este llamamiento de todas gentes, según parece en los judíos, moros y gentiles, que por su industria y cuidado han venido y vienen en conocimiento de nuestra santa fe católica, y á la obediencia de la santa Iglesia romana, desde el tiempo de los Reyes Católicos, que (como dicen) fué ayer, hasta el día de hoy. Y va el negocio adelante. Y es mucho de notar que las tres maneras de vocación expresadas en el Evangelio, ó tres salidas que hizo el siervo para llamar á la cena, concuerdan mucho con la diferencia de las tres naciones ya dichas, en cuyas sectas se incluyen todas las demás que hay esparcidas por el mundo (Mendieta, 1973: I, 4).

Mendieta, a diferencia del agustino y del jesuita que en ocasiones se mostraban ambiguos, es claramente contrario al uso de la violencia en la tarea evangelizadora de los indios, y denuncia las nefastas consecuencias de una mala interpretación de la parábola lucana: 
Y por tanto, de estos dijo Dios á su siervo: compélelos á que entren, no violentados ni de los cabellos con aspereza y malos tratamientos (como algunos lo hacen, que es escandalizarlos y perderlos del todo), sino guiándolos con autoridad y poder de padres que tienen facultad para ir á la mano á sus hijos en lo malo y dañoso, y para apremiallos á lo bueno y provechoso; mayormente á lo que son obligados y les conviene para su salvación (Mendieta, 1973: I, 4).

En definitiva, puede decirse que los principales comentaristas y misioneros de la época, al interpretar Lc 14,15-24, desestiman el uso de la violencia en la predicación evangélica, pero ciertas dosis de realismo, mezclado a veces de urgencia escatológica y otras de una visión paternalista del indio, les empujan a algunos de ellos a matizar esta afirmación y a reconocer que, en ocasiones, puede ser eficaz o necesaria.

\subsection{Andrés Pérez de Ribas}

Años más tarde, la cita lucana (y/o su paralelo mateano) volverá a ser utilizada por los misioneros de Indias, pero desprovista de la polémica sobre el ejercicio de la violencia, limitándose a mencionarla para decir que también los pobres y sencillos indios son llamados a la evangelización. Es el caso, por ejemplo, de Andrés Pérez de Ribas (15761647), provincial jesuita de Nueva España y después procurador o representante de la provincia mexicana en Roma, quien, en su Historia de los Triumphos de Nuestra Santa Fee entre gentes las mas barbaras, y fieras del Nuevo Orbe, obra publicada en Madrid en 1645, particularmente en la dedicatoria que hace al rey Felipe IV, combina Mt 22,9 y Lc 14,21:

En el Mandato, que dio este Señor a sus Ministros en su divina Parabola, no pudo dissimular aquel afecto de benignidad que brotó, para con pobres, y desechados, especificando, y mandando a sus criados, que de este genero de gente, combidassen a su Real combite (donde los manjares no eran menos preciosos que de gracia y gloria) a todos quantos encontrasen, por pobres y abatidos que fuesen: Ite ad exitus viarum, et quoscumque in veneritis vocate: dixo por san Mateo. Y san Lucas los expecificò mas, diciendo: Pauperes, ac debiles, et cacos, et claudos: en que estan expresadas las gentes ciegas de la Gentilidad, como lo entendio san Ambrosio (Pérez de Rivas, 1992: [ii]).

Al interpretar la parábola lucana, Pérez de Ribas ha abandonado la polémica en torno al compelle intrare, que ni menciona, y ha desplazado el interés de la misma hacia la preocupación del Señor por los pobres y abatidos que el jesuita entiende, en el marco de su misión evangelizadora, 
son los indios ${ }^{40}$. En esta ocasión, podría decirse que la parábola ha perdido la potencialidad de ser un «arma arrojadiza» contra los indios.

\section{Temas bíblicos en el teatro de evangelización}

Más allá de las prohibiciones de traducirla a las lenguas indígenas y de las tensiones dialécticas (en las que lamentablemente no podían participar los propios indios) provocadas por su utilización como fuente de inspiración para dilucidar las grandes cuestiones políticas y religiosas que se planteaban en relación al Nuevo Mundo, la Sagrada Escritura encontró un cauce de promoción aparentemente más tranquilo e incluso atractivo para los propios indios: la escenificación de obras teatrales o autos sacramentales. Así lo expresa Jerónimo de Mendieta: «Y en algunas partes hay representaciones de pasos de la Escritura sagrada, que todo ayuda para edificación del pueblo y aumento de solemnidad a la fiesta» (Mendieta, 1973: IV, 19).

Uno de los «doce apóstoles» franciscanos, fray Toribio de Benavente, conocido por los indios como Motolinía («pobrecito» en lengua náhuatl), alude, en su Tratado de los indios de la Nueva España (1541), a diversos autos de temática bíblica representados en Nueva España. En el contexto de las fiestas del Corpus Christi y San Juan que se celebraron en Tlaxcala en 1538, Motolinía señala que los indios representaron la Natividad de Juan el Bautista (Lc 1) (Benavente, 2001) y, junto al hospital, se escenificó un auto sobre «la caída de nuestros primeros padres» (Gn 3) en lengua náhuatl. La lengua indígena cobraba así un protagonismo que se le había negado en las traducciones escritas del texto bíblico.

Es interesante la interpretación que el auto hace de Gn 3,6. Eva insiste una y otra vez para que Adán tome la fruta, a lo que al principio éste se resiste indignado, con lo que se subraya la malicia pertinaz de la mujer. Tras el destierro de ambos del Paraíso quedan fijados algunos roles sexuales: el hombre debe labrar y cultivar la tierra y la mujer hilar y hacer ropa para su marido e hijos. Roles que se espera reproduzcan los indios. Motolinía enfatiza que la escena del destierro del Paraíso provocó el llanto de los indios. Cabría preguntarse si lo indios lloraron únicamente por el dramatismo de la escena o si también lo hicieron porque vieran en ella reflejado el destierro de sí mismos en sus propias tierras:

40 Este desplazamiento hermenéutico de la parábola que va del compelle intrare a la preocupación por los pobres y necesitados es propio de la exégesis más actual. Véase, por ejemplo, García (2012: 330). 
Lo que más fue de notar fue el verlos salir desterrados y llorando: llevaban a Adán tres ángeles y a Eva otros tres, e iban cantando en canto de órgano, Circumdederunt me. Esto fue tan bien representado, que nadie lo vio que no llorase muy recio; quedó un querubín guardando la puerta del paraíso con su espada en la mano. Luego allí estaba el mundo, otra tierra cierto bien diferente de la que dejaban, porque estaba llena de cardos y de espinas, y muchas culebras; también había conejos y liebres. Llegados allí los recién moradores del mundo, los ángeles mostraron a Adán cómo había de labrar y cultivar la tierra, y a Eva diéronle husos para hilar y hacer ropa para su marido e hijos (...).

Este auto fue representado por los Indios en su propia lengua, y así muchos de ellos tuvieron lágrimas y mucho sentimiento, en especial cuando Adán fue desterrado y puesto en el mundo (Benavente, 2001: 154).

Motolinía añade que también se representaron los autos de la conquista española de Jerusalén, el de las tentaciones de Jesús (Mt 4,1-11), y el «del sacrificio de Abraham»(Gn 22) (Benavente, 2001). Esta última obra, El sacrificio de Isaac (hacia 1536-1539), sobre la que no entra en detalles Motolinía, es muy importante y significativa por su temática. Según señala (Versényi, 1996: 42) ${ }^{41}$, se trata de un breve auto sacramental en el que se produce el intento de Hagar y de su hijo Ismael de corromper a Isaac tentándole para que desobedezca a su padre, y la disposición de Abrahán de sacrificar a su hijo amado. Ambas actitudes serán frustradas: la primera, gracias a la innata bondad de Isaac; la segunda, por medio del ángel que se aparece y detiene al patriarca. Esta obra exige la total obediencia a la autoridad, sea la de Dios, la de los padres e, implícitamente, la de otras personas que ejercen autoridad, como los mismos franciscanos. Al mismo tiempo hace hincapié en que el Dios cristiano es un Dios de gracia que no requiere sacrificios humanos. Un mensaje muy directo para la cultura azteca que los practicaba profusamente hasta la llegada de los españoles como bien detallaba el propio Motolinía (Benavente, 2001). No se incluye en la obra la sustitución de Isaac, como víctima propiciatoria, por un cordero, para evitar ofrecer a los indios ideas heréticas.

Otra obra interesante es La adoración de los Reyes (hacia 1540-1550), de carácter muy similar a la obra medieval El servicio para la representación de Herodes del Manuscrito de Fleury. Básicamente, se trata de la historia bíblica de la adoración de los Magos, de la ira de Herodes tras la consulta a sus sacerdotes, su intento de engañar a los Magos, la visita de éstos al pesebre y su posterior escapatoria (Mt 2). La obra contiene nahuatlismos. Los paralelismos existentes entre esta historia y la de los acontecimientos

41 Sobre el teatro de evangelización en México, pueden verse también, entre otros, Salinas (2005) y Esquivel Estrada (2008). 
reales de la Conquista, cuando Moctezuma II estaba aterrorizado ante la presencia de un cometa y otros augurios previos a la llegada de los españoles, pudieron influir emocionalmente en el público, «haciendo a los indios más susceptibles al mensaje cristiano inherente a la obra» (Versényi, 1996: 43). Podría decirse que estas obras conllevaban un mensaje subliminal que buscaba la descodificación o deconstrucción de los viejos patrones culturales de los indios.

El teatro «evangelizador» tuvo un gran desarrollo durante el siglo XVII, época de grandes campañas de extirpación de idolatrías especialmente en el Perú ${ }^{42}$, que, sin embargo, no fueron tan eficaces como pensaron sus promotores ${ }^{43}$. Este teatro se convirtió en una manera distinta de superar la idolatría mediante una evangelización más próxima al indio, y en especial a su cultura de la palabra. Contribuyeron a ello algunas obras que intentaron que la doctrina, e incluso la Sagrada Escritura, estuvieran más directamente al alcance de los indios. Así, el jesuita italiano Ludovico Bertonio publicó en 1612 la obra titulada Vida y Milagros de Nuestro Señor Jesucristo en aymara y en romance castellano ${ }^{44}$, en la que, a través de cincuenta y un capítulos, se presentaba la vida de Jesucristo acompañada de amplias referencias a los textos evangélicos, incluyendo, a modo de apéndice, la traducción en aymara de algunos evangelios dominicales y fiestas. Junto a esta obra cabe destacar La Cristiada del dominico fray Diego de Hojeda, publicada en 1611 en Sevilla pero después de haber sido escrita en Lima. Está compuesta en versos distribuidos en octavas a través de doce libros que presentan la vida de Cristo desde la Última Cena hasta su muerte en Cruz y entierro en el sepulcro. Valga de ejemplo el siguiente fragmento que reproduce parte del diálogo entre Jesús y Pedro en el lavatorio de los pies de la Última Cena:

Llegó pues Cristo, puso en tierra el vaso,

42 Celo denunciado por Poma de Ayala (1987), quien considera que los sacerdotes deberían preocuparse más por la predicación del Evangelio y de las Sagradas Escrituras que por las «huacas» o lugares sagrados de los indios.

43 Como sostiene Gareis (2004), las comunidades indígenas se resistieron a la extirpación y en sucesivas campañas adoptaron diversas estrategias que les permitieran continuar con sus creencias, si bien éstas experimentaron modificaciones que en ocasiones alteraban la cohesión social que anteriormente proporcionaban al grupo: «Las campañas de extirpación de las idolatrías tuvieron un éxito parcial al fraccionar los grandes cultos regionales, pero no lograron destruir ni hacer desaparecer totalmente las religiones andinas. Éstas, según parece, más bien se acomodaron en el nicho que les había quedado» (Gareis, 2004: 280).

44 El título completo de la obra es Libro de la Vida y Milagros de Nuestro Señor Jesucristo en dos Lenguas Aymara y Romance y traducido del que recopiló el Lic. Alonso de Villegas quitadas y añadidas algunas cosas y acomodado a la capacidad de los Indios, Francisco del Canto Editor, Impreso en la Casa de la Compañía de Jesús del Pueblo de Juli, 1612. 
El lienzo apercibió, tendió la diestra,

Y absorto Pedro de tan nuevo caso,

Aun mas no viendo que una simple muestra,

Saltó animoso, dando atras un paso

(Que el osado el amor valiente adiestra),

Y dijo: "¿Para aquesto me buscabas

Tú á mí, Señor? ¿Tú á mí los piés me lavas? (Seibold, 1993: 89)

Otras obras de temática claramente bíblica, a cargo de los jesuitas, fueron La historia de José, el anciano patriarca, representada en 1607 (Gn 3750), o el Arca de Noé (Gn 6-9), representada en 1672 (Salazar Zagazeta, 2003). Como señala (Seibold, 1993: 89), será la muestra «de un género que luego se reproducirá abundantemente en nuestra América en los siglos XVII, XVIII y XIX y de la cual todavía hoy puede encontrarse una rica y viva tradición oral de temática bíblica puesta en villancicos, romances, canciones y coplas, etc. que canta o recita el pueblo en muchos de nuestros países, y que debe remontarse probablemente a esos lejanos antecedentes de la primera evangelización americana».

De este modo, a pesar de la prohibición de traducir la Sagrada Escritura, ésta siguió formando parte ineludible del proceso evangelizador de los indios del Nuevo Mundo durante los siglos XVI y siguientes. Otra cosa bien distinta es la manera en que unos y otros la utilizaron para justificar distintas opciones misioneras y políticas no siempre acordes con el verdadero sentir del Evangelio.

\section{A modo de conclusión}

La Sagrada Escritura fue uno de los instrumentos principales, si no el principal, con el que los cronistas y misioneros del siglo XVI intentaron comprender la realidad compleja del Nuevo Mundo recién «descubierto». Fue la Palabra de Dios que los misioneros quisieron transmitir e implantar entre los indios, y, en ocasiones, fue también la fuente de inspiración de políticos y religiosos que intentaban desde ella dar respuesta a los grandes conflictos provocados por el (des)encuentro entre culturas y religiones distintas.

Los primeros misioneros intentaron primero explicar y luego traducir la Biblia a las lenguas autóctonas para que los indios pudieran comprenderla. Pero la negativa de las autoridades eclesiásticas a dichas traducciones impidió que los indios tuvieran acceso directo a la misma, lo que suponía la imposibilidad no sólo de comprenderla adecuadamente, sino también de descubrir en ella textos potencialmente liberadores para 
ellos. Además, su propia lengua quedaba implícitamente desautorizada como vehículo de los textos sagrados.

No obstante esta difícil realidad, la Sagrada Escritura mantuvo su protagonismo. Cronistas y misioneros de diferentes tendencias acudieron a la Biblia para encontrar argumentos que legitimaran sus diferentes posturas en orden al hipotético derecho de conquista del Nuevo Mundo, de la guerra justa contra los indios o de la forma en que debía implantarse el cristianismo. Un claro ejemplo de esto fue la polémica en torno a la cita de Lc 14,23, la cual, según algunos que se amparaban en la interpretación dada por Agustín de Hipona de las palabras compelle intrare, justificaba el uso de la fuerza en aras de la conversión de los indios.

Las posturas oscilaban desde quienes interpretaban que la cita legitimaba el uso de la fuerza (Ginés de Sepúlveda), pasando por quienes mostraban una postura ligeramente ambivalente pero orientada fundamentalmente a la negación de la conversión forzosa (León y Acosta), hasta quienes se oponían con rotunda claridad a cualquier tipo de imposición forzada de la fe (Las Casas y Mendieta). Pasará un tiempo antes de que la polémica en relación al compelle intrare de Lc 14,23 desapareciera y la parábola lucana fuera interpretada de una manera más benévola para los indios (por ejemplo, Pérez de Rivas), pero la tendencia mayoritaria entre los comentaristas y misioneros de la época fue la de desestimar la interpretación de la evangelización forzosa. En todo caso, todas estas posturas estaban condicionadas por una visión del «otro», del indio, que también oscilaba entre la imagen servil del cuasi esclavo (Ginés de Sepúlveda), la del niño a quien hay que educar con firmeza (Acosta) y la del hombre «hermano» y crucificado (Las Casas).

Finalmente, el teatro de «evangelización», floreciente a partir de los siglos XVI y XVII, fue una manera alternativa, práctica y visual, de transmitir la Sagrada Escritura a los indios a través de las representaciones de diversos episodios bíblicos. En ocasiones, lo hizo recuperando el valor de las lenguas indígenas para la transmisión del mensaje bíblico, pero su uso no fue inocente porque sirvió hábilmente para deconstruir y decodificar los viejos patrones culturales y religiosos de los indios.

Por tanto, la Sagrada Escritura fue para la Iglesia y la política del siglo XVI fuente principal de inspiración para afrontar los problemas y expectativas del Nuevo Mundo. Que pudiera ser también instrumento de liberación o de dominación de los indios dependía, como también hoy día, de los intereses hermenéuticos de sus intérpretes. 


\section{REFERENCIAS}

-Acosta, J. de (1984). De procuranda indorum salute (L. Pereña, V. Abril, C. Baciero, A. García, D. Ramos, J. Barrientos \& F. Maseda, Eds.). Madrid: Consejo Superior de Investigaciones Científicas.

-Acosta, J. de (2008). Historia natural y moral de las Indias (F. del Pino-Díaz, Ed.), Madrid: Consejo Superior de Investigaciones Científicas.

-Agustín (1951). Obras de San Agustín. Tomo VIII. Cartas (L. Cilleruelo, Ed.) Madrid: Biblioteca de Autores Cristianos.

-Alonso, V. (1988). La Biblia en el Nuevo Mundo. Revista Bíblica (50), 125-133.

-Arroyo, M. (1993). El P. José de Acosta, S.J. (1540-1600) y la educación de los indios de América. Theologica Xaveriana (43), 353-372.

-Baudot, G. (1983). Utopía e Historia en México. Los primeros cronistas de la civilización mexicana (1520-1569). Madrid: Espasa-Calpe.

-Benavente, T. de (2001). Historia de los indios de la Nueva España. Edición de Claudio Esteva Fabregat. Madrid: Dastin.

-Borges, P. (1976). Observaciones sobre la reacción al cristianismo de los aztecas, mayas e incas. En Simposio Conmemorativo del V Centenario del Padre Las Casas. Terceras Jornadas Americanistas de la Universidad de Valladolid. En Seminario de Historia de América (Ed.), Estudios sobre política indigenista española en América (T. II, págs. 71-83). Valladolid: Universidad de Valladolid.

-Borges, P. (1987). Misión y civilización en América. Madrid: Alhambra.

-Castillo Mattasoglio, C. (1993). Libres para creer. La conversión según Bartolomé de Las Casas en la Historia de las Indias. Lima: Pontificia Universidad Católica del Perú.

-Dehouve, D. (2000). Un diálogo de sordos: los Coloquios de Sahagún. En A. Monod Becquelin \& P. Erikson (Eds.), Les rituels du dialogue (págs. 199234). Nanterre: Société d'ethnologie.

-Durán, J. G. (1984). Monumenta Catechetica Hispanoamericana (Vol. I, siglo XVI) Buenos Aires: Ediciones de la Facultad de Teología de la UCA.

-Esponera Cerdán, A. (1990). El punto de partida de la hermenéutica bíblica de Bartolomé de Las Casas (1559-1564). En Facultad de Teología San Vicente Ferrer de los Padres Dominicos (Eds.), La palabra de Dios y la hermenéutica: a los 25 años de la constitución Dei Verbum del Concilio Vaticano II: actas del VI Simposio de Teología Histórica (14-16 noviembre 1990) (págs. 379-398). Valencia: Facultad de Teología San Vicente Ferrer.

-Esquivel Estrada, N. H. (2008). El teatro del siglo XVI como instrumento de evangelización. Tópicos (34), 285-308.

-Fitzmyer, J. A. (1987). El Evangelio según Lucas. III. Traducción y comentario. Capitulos 8,22-18,14 (D. Míngez, Trad.) Madrid: Ediciones Cristiandad.

-Frades, E. (1997). El uso de la Biblia en los escritos de Fray Bartolomé de Las Casas. Caracas-Venezuela: Instituto Universitario Seminario Interdiocesano Santa Rosa de Lima. 
-Galván Rivera, M. (1859). Concilio III Provincial Mexicano, celebrado en México el año de 1585, confirmado en Roma por el Papa Sixto $V$, y mandado observar por el Gobierno español en diversas reales órdenes. México: Eugenio Maillefert y Compañía.

-García, S. (2012). Evangelio de Lucas. Bilbao: Desclée de Brouwer.

-García Icazbalceta, J. (1947). Don Fray Juan de Zumárraga (Vol. II). México: Porrúa.

-García Izcabalceta, J. (1971). Colección de Documentos para la Historia de México (Tomo II) México: Porrúa.

-Gareis, I. (2004). Extirpación de idolatrías e identidad cultural en las sociedades andinas del Perú virreinal (siglo XVII). Boletín de Antropología (18), 262 282.

-Gil, F. (2006). La evangelización franciscana del Nuevo Mundo y la educación. De la 'Tlacahuapahualiztli' náhualt a una pedagogía del encuentro. Nuevo Mundo (7), 3-26.

-Ginés de Sepúlveda, J. (1984). Demócrates Segundo o de las justas causas de la guerra contra los indios. Edición crítica bilingüe, traducción castellana, introducción, notas e indices por Ángel Losada. Madrid: C.S.I.C.-Instituto Francisco de Vitoria.

-Gómez Canedo, L. (1976). Evangelización y política indigenista. Ideas y actitudes franciscanas en el siglo XVI. En Simposio Conmemorativo del V Centenario del Padre Las Casas. Terceras Jornadas Americanistas de la Universidad de Valladolid, Estudios sobre política indigenista española en América (Tomo II, págs. 21-46). Valladolid: Universidad de Valladolid.

-Gómez Díez, J. (2000). El impacto de las religiones americanas en la teología misionera del s. XVI. Bilbao: Desclée de Brouwer.

-González Rodríguez, J. (1992). La difusión manuscrita de ideas en Nueva España (siglo XVI). Revista Complutense de Historia de América (18) 89-116.

-González Rodríguez, J. (1997). Lecturas e ideas en Nueva España. Revista Complutense de Historia de América (23) 39-74.

-Hernández Martín, R. (2004). Dictamen teológico-misional de 1541. Recuperado el 7 de diciembre de 2013, de http:/ / angarmegia.com/zumarraga.htm.

-Höffner, J. (1957). La ética colonial española del Siglo de Oro. Madrid: Ediciones Cultura Hispánica.

-Las Casas, B. de (1989). Apología. En A. Losada, Fray Bartolomé de Las Casas. Obras completas (Vol. 9). Madrid: Alianza Editorial.

-Las Casas, B. de (1990). De único vocationis modo. En P. Castañeda \& A. García, Obras completas. Madrid: Alianza Editorial.

-Las Casas, B. de (1994). Historia de las Indias. En M. Medina, J. Barreda, Isacio Pérez Fernández, Fray Bartolomé de Las Casas. Obras completas (Vols. 3-5). Madrid: Alianza Editorial.

-León, J. L. de (2006). El 'Libro de las Profecías' (1504) de Cristóbal Colón: la Biblia y el Descubrimiento de América. Helmántica, LVII (172), 77-123.

-León, J. L. de (2008). La Biblia y la dignidad de los indios del Nuevo Mundo. O cuando la teología ilumina la política de una época. En C. Bernabé \& C. 
Gil (Eds.), Reimaginando los orígenes del cristianismo. Relevancia social y eclesial de los estudios sobre Orígenes del cristianismo (págs. 433-467). Estella: Verbo Divino.

-León, J. L. de (2009). Ediciones totales y parciales de la Biblia en lengua española realizadas en Hispanoamérica. Letras de Deusto, 39 (125), 165-213.

-León Pinelo, A. de \& Solórzano, J. de (1680). Recopilación de las Leyes de los Reynos de las Indias. Edición digitalizada. Recuperado el 7 de diciembre de 2013, de http://www4.congreso.gob.pe/ntley/LeyIndiaP.htm.

-León-Portilla, M. (1987). Bernardino de Sahagún. Madrid: Historia 16-Quorum.

-Lorenzana, F. A. (1769). Concilios Provinciales Primero y Segundo celebrados en la muy Noble y muy Leal Ciudad de México presidiendo el Ilmo. y Rmo. Sr. D. Fr. Alonso de Montúfar en los años 1555 y 1565. México: Imprenta de el Superior Gobierno, de el Br. D. Joseph Antonio de Hogal, en la Calle de Tiburcio.

-Losada, A. (1976). Exposición analítica de la Apología de Juan Ginés de Sepúlveda, en pro de su libro Democrates II. En Seminario Americanista de la Universidad de Valladolid, Juan Ginés de Sepúlveda y su crónica indiana. En el IV centenario de su muerte 1573-1973 (págs. 35-61). Valladolid: Seminario Americanista de la Universidad de Valladolid y Excmo. Ayuntamiento de Pozoblanco.

-Martínez Ferrer, J. (2006). La primera visión de Fray Juan de Zumárraga de los indígenas mexicanos (1528-1533). Archivo Ibero-Americano (66), 241-268.

-Medina, J. T. (1912). La imprenta en México (1539-1821) (Tomo I). Santiago de Chile: Impreso en Casa del Autor.

-Medina, J. T. (1956). Historia del Tribunal de la Inquisición de Lima: 1569-1820 (Tomo I). Santiago de Chile: Fondo Histórico y Bibliográfico José Toribio Medina.

-Mendieta, J. de (1973). Historia Eclesiástica Indiana (F. Solano \& L. Pérez, Eds., 2 vols.) Madrid: Biblioteca de Autores Españoles.

-Morales, F. (2001). Los 'Colloquios' de Sahagún: el marco teológico de su contenido. Estudios de Cultura Nábuatl (32), 175-188.

-Moreno A. \& Martos, J. (1999). Fray Luis de León. Escritos sobre América. Madrid: Tecnos.

-Osuna, A. (1975). El tratado de 'Las doce dudas' como testamento doctrinal de Bartolomé de Las Casas. Ciencia Tomista (102), 325-378.

-Pérez de Rivas, A. (1992). Historia de los Triumphos de Nuestra Santa Fee entre gentes las mas barbaras, y fieras del Nuevo Orbe [edición facsimilar] (Ignacio Guzmán Betancourt, Ed.) México: Siglo Veintiuno Editores- Difocur-Sinaloa.

-Polanco Martínez, F. (2000). La lengua de la evangelización y de la enseñanza en las crónicas de Motolinía y Reginaldo de Lizárraga. Espéculo. Revista de estudios literarios (6). www.ucm.es/info/especulo/numero14/le_evang.html.

-Poma de Ayala, F. G. (1987). Nueva crónica y buen gobierno (J. V. Murra, R. Adorno \& J. L. Urioste, Eds. Tres tomos). Madrid: Historia 16.

-Sahagún, B. de (1986). Coloquios y Doctrina cristiana. Los diálogos de 1524 según el texto de Fray Bernardino de Sahagún y sus colaboradores indígenas (M. LeónPortilla, Ed.). México: UNAM, Instituto de Investigaciones Históricas. 
-Salazar Zagazeta, C. M. (2003). El teatro 'evangelizador' y urbano en los Andes: encuentros y desencuentros. Criticón (87-89), 775-786.

-Salinas, J. R. (2005). La pastorela y el diablo en México. México: Porrúa.

-Santo Tomás, D. de (1995). Gramática o arte de la lengua general de los indios de los reynos del Perú por el maestro Fray Domingo de Santo Tomás de la orden de Santo Domingo (R. Cerrón-Palomino, Ed). Cuzco: CBC-Centro de Estudios Regionales Andinos "Bartolomé de Las Casas".

-Schmid, J. (1968). El Evangelio según San Lucas (M. González-Haba, Trad.). Barcelona: Herder.

-Seibold, J. (1992). La 'palabra' en el mundo cultural precolombino. Pueblo de Dios y palabra de Dios: La actualización de la Sagrada Escritura en la Evangelización de Americana Latina. Cuarta Parte. Stromata (48), 243-286.

-Seibold, J. (1993). La Sagrada Escritura en la primera evangelización del Virreinato del Perú. Stromata (49), 55-108.

-Sievernich, M. (2007). Conquistar todo el mundo: los fundamentos espirituales de las misiones jesuíticas. En K. Kohut-M. C. Torales Pacheco (Eds.), Desde los confines de los imperios ibéricos. Los jesuitas de habla alemana en las misiones americanas (págs. 3-23). Frankfurt-Madrid: Vervuert-Frankfurt-Iberoamericana.

-Sosa, P. de (1848). Memorial del peligroso estado espiritual y temporal del Reyno de Chile. En J. Toribio Medina, Biblioteca Hispano-Chilena (1523-1817) (Tomo II, págs. 158-193). Santiago de Chile: Impreso y Grabado en casa del Autor.

-Todorov, Tz. (1998). La conquista de América. El problema del otro. MéxicoMadrid: Siglo XXI.

-Vargas Ugarte, R. (1955). Los Concilios Limenses (Tomo I). Arzobispado de Lima: Lima.

-Versényi, A. (1996). El teatro en América Latina. Cambridge: Cambridge University Press.

-Xerez, Fr. de (1985).Verdadera relación de la conquista del Perú y Provincia de Cuzco (Concepción Bravo, Ed.) Madrid: Historia 16.

-Yates, B. (2008). El Tratado sobre la fe: El argumento de Fray Luis de León sobre el uso de la fuerza para evangelizar a los indios. Dissidences. Hispanic Journal of Theory and Criticism, 3 (5), 1-16.

Sumario: Introducción. 1. Las primeras versiones de la Biblia en lenguas indígenas: un intento frustrado; 2. Lc 14,23, una cita controvertida: ¿Evangelización pacífica o forzada?; 2.1. Juan Ginés de Sepúlveda; 2.2. Bartolomé de Las Casas; 2.3. Luis de León; 2.4. José de Acosta; 2.5. Jerónimo de Mendieta; 2.6. Andrés Pérez de Ribas; 3. Temas bíblicos en el teatro de evangelización; A modo de conclusión. Referencias. 